\title{
A Review on Organic Pistachio Growth and Development Opportunities in Turkey
}

\author{
Mikdat Şimşek ${ }^{1} \quad$ Ersin Gülsoy $2^{2 *}$ \\ ${ }^{1}$ Department of Horticulture, Faculty of Agriculture, Dicle University, Diyarbakır, Turkey \\ ${ }^{2}$ Department of Horticulture, Faculty of Agriculture, Iğdır University, Iğdır, Turkey
}

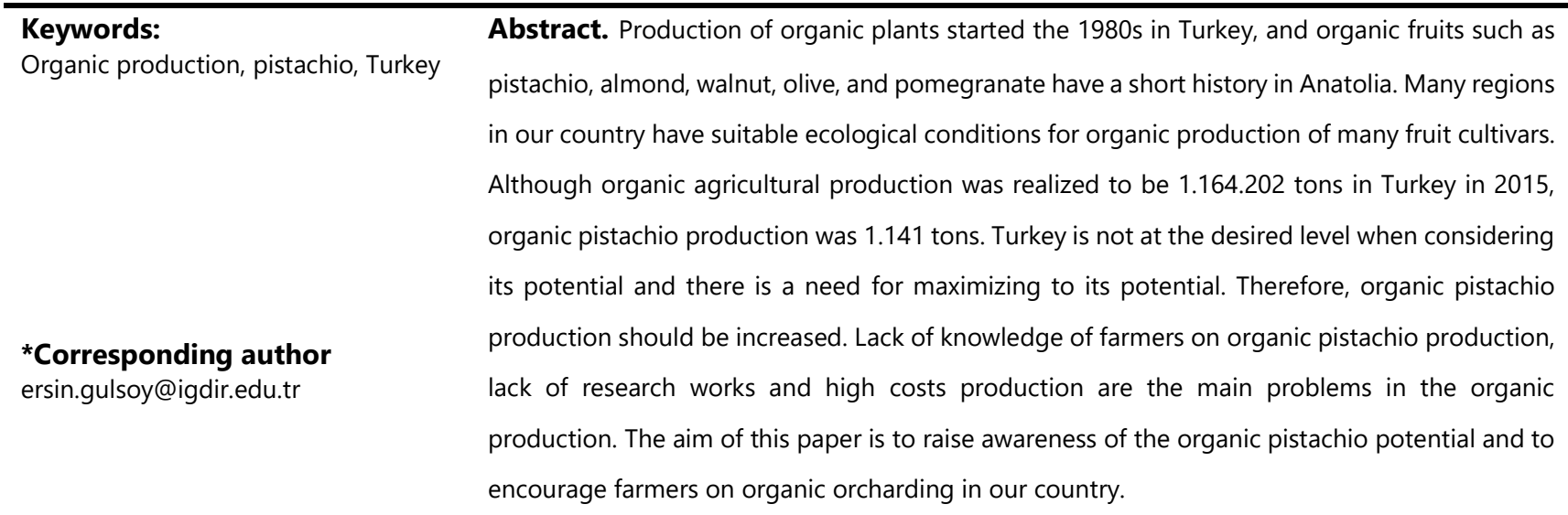

Türkiye'de Organik Antepfıstığı Yetiştiriciliği ve Geliştirme Olanakları Üzerine Bir Derleme

\section{Anahtar kelimeler:}

Organik üretim, Antep fıstığı, Türkiye

\begin{abstract}
Özet. Türkiye de organik tarım 1980 lerde başlamıştır ve antep fıstığı, badem, ceviz, zeytin, nar gibi meyvelerin Anadolu da organik olarak üretilmesi kısa bir geçmişe sahiptir. Ülkemizdeki birçok bölge, çoğu meyve türünün organik üretimi için uygun ekolojik koşullara sahiptir. Türkiye de organik tarım üretimi 2015 yılında 1.164.022 ton gerçekleşmesine ragmen, organik antep fıstığı üretimi 1.141 ton da kalmıştır. Türkiye'nin organik tarım üretim potansiyeli göz önüne alındığında, üretimin istenilen seviyede olmadığı ve bu potansiyelin üst düzeye çıkarılması gerektiği söylenebilir. Bundan dolayı organik tarım üretimi arttııımalıdır. Organik tarım üretiminde, araştırma sayısının az olması, çiftçilerin bilgi eksikliği ve üretimde maliyetlerin yüksek olması organik tarım üretimini sınırlamaktadır. Bu çalışmada organik antep fıstığı potansiyeli ortaya konularak bu konudaki farkındalığı arttırmak ve çiftçileri organik meyve bahçeleri kurmaya teşvik etmek amaçlanmaktadır.
\end{abstract}




\section{INTRODUCTION}

Organic farming is a method of crop and livestock production that involves much more than choosing not to use pesticides, fertilizers, genetically modified organisms, antibiotics and growth hormones. Organic production is a holistic system designed to optimize the productivity and fitness of diverse communities within the agro-ecosystem, including soil organisms, plants, livestock and people. The principal goal of organic production is to develop enterprises that are sustainable and harmonious with the environment (IOF 2018).

Pistachio (Pistacia vera L.) is one of the most important nuts in the world due to its special organoleptic characteristics (Acena et al., 2010; Tsantili et al., 2010). This species has been used as a savory snack or as a major ingredient in many traditional desserts, pastries, fermented meats, and puddings throughout human history. Today, pistachios are cultivated as an important agricultural commodity in Iran, Turkey, the United States, Syria, Greece, Italy, and Spain (Rodriguez-Bencomo et al., 2015). After Iran and USA, Turkey is the third biggest importer and exporter of pistachio nuts (FAO 2015).

Many fruit species were grown in Anatolia a few thousand years ago (Gercekcioglu et al., 2014; Şimşek 2015; Gülsoy et al., 2016). In this context, Turkey is the motherland of many nuts, such as pistachio, walnut, hazelnut, chestnut, and almond (Sykes 1975; Soylu 1984; Köksal 2002; Akça 2009; Balık et al., 2016).

All kinds of pistachio are conventionally produced in Anatolia (Satil et al., 2003). In addition, grafted pistachio cultivars on wild Pistachio species are also grown in different regions of Turkey (Kaska 1995). Therefore, the production of pistachio in Turkey has increased in recent years. But, organic pistachio production was 1.141 tons in Anatolia. This fruit production is not at the desired level when considering its potential in Turkey. According to agricultural certificate, 30 Turkish Liras per decare for organic pistachio are given organic production support (RG, 2017). It is a system which is the guarantor for the consumer of the inspection and certification bodies certified by ISO 65 (EN45011) certification. The farmers who produce organic pistachios must produce in accordance with the principles of the certification body (OTKS 2018). Organic products have been more consuming by people in developed countries (Kaya 2003). However, organic pistachios are evaluated as fresh, salted, roasted, sweetened and in the industry. Some projects such as organic pistachio breeding and the improvement of biological substructure in pistachio have been finalized. Pistachio cultivars such as Siirt, Uzun, Kirmizi and Ohadi and pistachio rootstocks such as buttum, menengic and atlantic sakizi are common. For example, vaccination of the Siirt variety on the Buttum mother can provide a good product. However, new rootstocks and varieties that can be used for different purposes in my country should be developed by working diligently on rootstock and variety breeding.

The soil should be selected according to the requirements of the organic pistachio. Organic pistachio seedlings must be intact, free of disease and harmful substances, and must be produced in clean areas. If cultivation area is affected by a certain disease and pest is common, using diversification on it will help to facilitate agricultural warfare in the future. In general, tillage, pruning, fertilization, irrigation, asthma and aggression must be cautious in the subject. In addition, if some of the live and inanimate materials with the following names using organic fruit clusters are needed, they can be evaluated in cultural measures in pistachio farming. These are: stable, compost, agricultural lime, leonardite, organic wastes, pit and peat, perlite, phosphate rock, potas rock, poultry waste, bordeaux slurry, arab soap, tobacco water, garlic water, milkweed water, raw milk, odor calcium polysulphite, potassium permanganate, azadirachtin, pyretherum, mineral oils, wax, thyme oil, rose essence, arabic soap, paraffin oils, pigment oils, light traps, food traps, visual traps, hunter insects, some copper compounds, sulfur, rock flour and bacillus thuringiensis (Şimşek 2015).

Stable fertilizer can be given 2-4 tons once every 23 years to soil of organic pistachio. Peat and Shrub soils area can evaluation for organic pistachio orcharding. Green manure such as alfalfa and kongkunga can be evaluated in organic pistachio fields. Microbial fertilizers are rich in nutrients that will increase production during the production of organic pistachios. Organomineral fertilizers contain both mineral nutrients and at least $15 \%$ organic matter and can be increase production during the production of organic pistachios. Microbiological fertilizer is useful for the improvement of organic pistachio soil. Bacteria, Actinomycetes, Mycorrhizae, Algae and Worms can be evaluated in organic pistachio farming (biological fertilization) (Şimşek 2013).

The use of compost can be achieved by using different methods and techniques from all kinds of vegetable and animal organic substances that we take 
out of the system in various meanings, and by application in various forms in accordance with the purpose of the breeding technique and purpose. Thus, resources are gained by evaluating the waste materials and the contamination and deterioration of the natural resources formed by storing the organic garbage in inappropriate conditions is prevented (Şimşek 2013).

Pistachio is one of the most popular tree nuts in the World (Aldars-Garcia et al., 2016). This fruit is the richest fatty-acids, metals and phytosterols, phenolic compounds (Dreher 2012). Because the pistachio is rich in nutrient content, this fruit must be produced more organically. Therefore, in this study, through presenting the existing status of organic pistachio production, it was aimed to increase the awareness and keep light to decision- makers in Anatolia.

\section{ORGANIC PISTACHIO'S PRODUCTION IN TURKEY}

The world has about 1.023 .000 tons of total pistachio production. The largest producer of pistachio in the world is Iran with 480.000 tons. After Iran, USA, Turkey, China and Syria produce 240.000, $144.000,80.000$ and 57.000 tons annually, respectively (FAO 2015). In addition, about 20 pistachio cultivars are grown in Turkey. The names of these cultivars are Siirt, Uzun, Kırmızı, Halebi, Ohadi, Keten Gömleği, Beyaz Ben, Değirmi, Çakmak, Sultani, Vahidi, Mümtaz, Sefidi and $\mathrm{HaCl}$ Şerifi. Some pistachio cultivars are given in Figure 1; Siirt pistachio cultivar is given figure 2. Kırmızı pistachio cultivars is given in Figure $3, a$ pistachio tree is given Figure 4 and the map of provinces having organic pistachio growth in Turkey is given in Figure 5 . The most popular pistachio cultivars in our country are Siirt, Kırmızı, Ohadi, Kellekoçi, Uzun and Halebi (Gezginç ve Duman 2004). The fruit appearances of Siirt and Kırmızı varieties are shown in figure 2 and 3 . Although there are so many pistachio varieties and pistachio production, until now organic pistachio production is 1.141 tons (RTMFAL 2015) and this production amount is very small. But, the ecological conditions of many provinces in Anatolia are suitable for growing organic pistachios. Therefore, the production of organic pistachios should be increased.

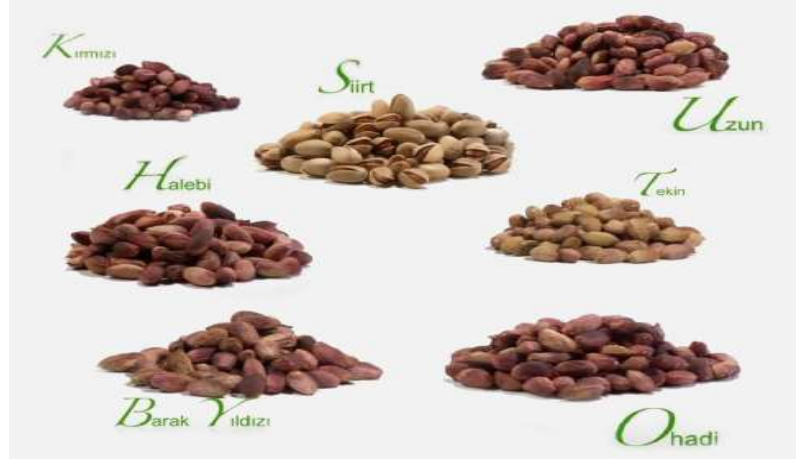

Figure 1. Some pistachio cultivars (SPC 2017).

Şekil 1. Bazı antepfıstığı çeşitleri (SPC 2017).

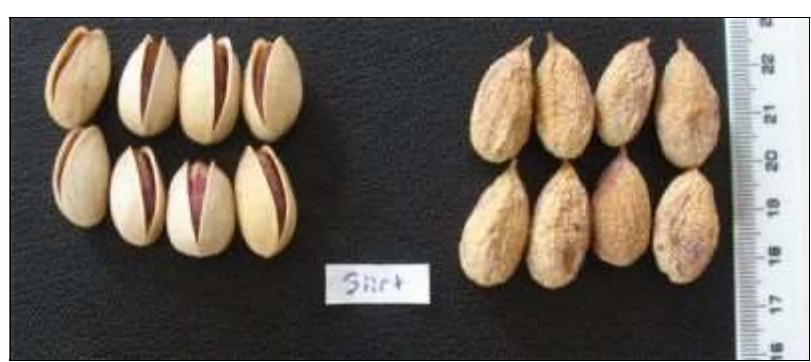

Figure 2. Siirt pistachio (SP 2017).

Şekil 2. Siirt fıstığı (SP 2017).

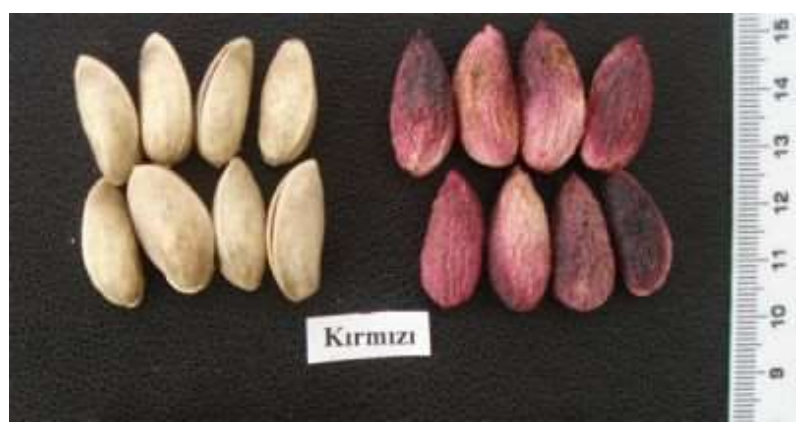

Figure 3. Kırmızı pistachio cultivar (KPC 2017). Şekil 3. Kırmızı antep fıstığı çeşidi (KPC 2017).

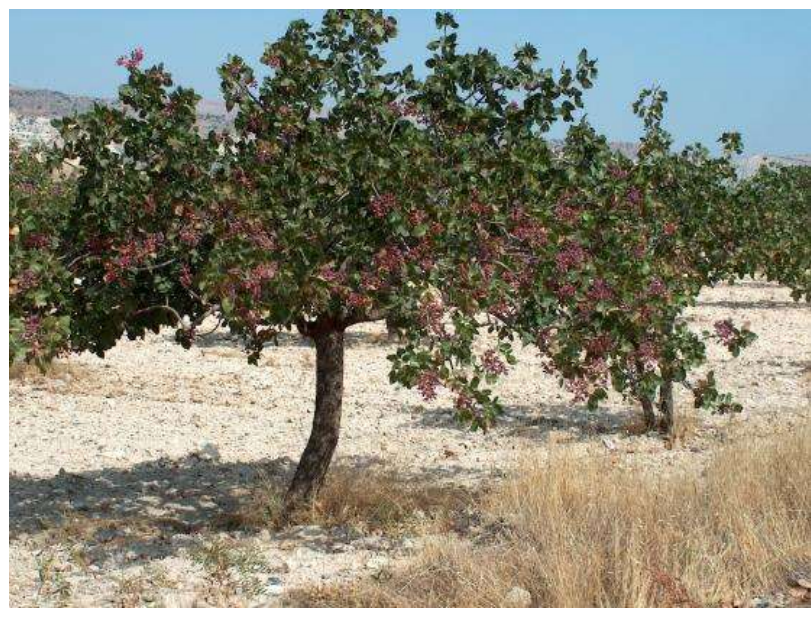

Figure 4. Pistachio Tree (PT 2017).

Şekil 4. Antep fıstığı ağacı (PT 2017). 


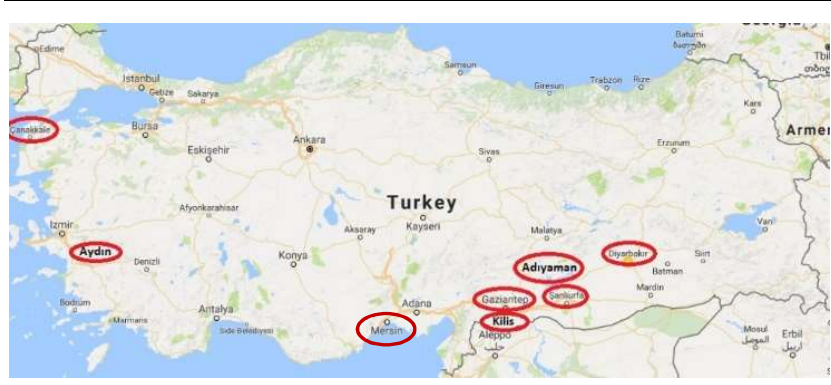

Figure 5. Map of provinces having organic pistachio production in Turkey (MPOPP 2017).

Şekil 5. Turkiyede organik antepfıstığı yetiştirilen illerin haritası (MPOPP 2017).

\section{ORGANIC PISTACHIO GROWTH OF OUR PROVINCES}

The map of our provinces having organic pistachio production is given in Figure 5. Although pistachio growth is traditionally grown in 40 provinces of Turkey (TSI 2015), organic pistachio production is grown on 8 provinces of Turkey (RTMFAL 2015). Considering the provinces in Turkey, Gaziantep and Şanlıurfa rank first and second with 646 and 412 tons of pistachio productions respectively. After these provinces, Adıyaman, Kilis, Diyarbakır, Aydın and Çanakkale produce $38,21,12,11$ and 2 tons, respectively as Mersin province come last with a production of only 1 ton (RTMFAL 2015). This production amount is very small despite, the ecological conditions of these provinces are suitable for growing organic pistachios. Therefore, the production of organic pistachios should be increased in these provinces.

\section{DEVELOPMENT OPPORTUNITIES OF PISTACHIO IN TURKEY}

Organic pistachio growth in Turkey needs to develop policies to get the expected profit from shell nuts together with production plans for domestic consumption and exports. These producers need to make regular cultural processes to reduce profit inefficiency. Organic pistachio yield and quality will increase in case of more contribution to scientific research and will make a positive contribution to the economy. Organic pistachio's fruits are in the group of risky products in terms of Aflatoxin. Technical and scientific studies must be done to reduce input cost in organic pistachio production.

\section{CONCLUSION}

Pistachio growth and production potential are very important for Turkey. Although pistachio production is traditionally grown on fourty provinces in Turkey, organic pistachio production is grown in eight provinces. Organic pistachio production is very small in Anatoli. Therefore, this nut producers should act in cooperation with other institutions and organizations, for example, agricultural faculties, and other colleges and the universities's institutes and Ministry of Food, Agriculture and Livestock. In provinces where organic pistachios grow, organic production and marketing strategies should urgently be developed. In addition, the programs supporting producers as making aware of the consumers for organic pistachio growth should be prepared and implemented. Because Gaziantep, Şanlıurfa, Adıyaman, Kilis and Diyarbakır provinces are suitable for organic pistachio production.

\section{REFERENCES}

Acena L., Vera L., Guasch J., Busto O and Mestres M., 2010. Comparative study of two extraction techniques to obtain representative aroma extracts for being analysed by gas chromatography-olfactometry application to roasted pistachio aroma. Journal of Chromatography, 1217(49): 7781-7787.

Akça Y., 2009. Ceviz Yetiştiriciliği. Anı Matbaası, Ankara.

Aldars-García L., Ramos AJ., Sanchis V and Marín S., 2016. Modelling the probability of growth and aflatoxin B1 production of Aspergillus flavus under changing temperature conditions in pistachio nuts. Procedia Food Science, 7: 76-79.

Balık Hi., Balık Kayalak S., Beyhan N ve Erdoğan V., 2016. Fındık Çeşitleri. Trabzon Ticaret Borsası, Klasmat Matbaacılık, Trabzon.

Dreher ML., 2012. Pistachio nuts: composition and potential health benefits. Nutrition Review, 70: 234-240.

FAO 2015. Food and Agriculture Organization Pistachio production http://faostat.fao.org/ [Access: June 1, 2017].

Gercekcioglu R., Bilgener S and Soylu A., 2014. General Orcharding (Principles of Fruit Growing). Nobel Academic Publishing, Improved $4^{\text {th }}$ Edition, Istanbul.

Gezginç Y ve Duman AD., 2004. Antep fıstığı işleme tekniği ve muhafazasının kalite üzerine etkisi. Gıda Teknolojisi Derneği (GTD) yayını, 5: 239-244.

Gülsoy E., Kaya T., Şimşek M and Pehluvan M., 2016. Selections of walnut (Juglans regia L.) in Igdir district. Iğdır University Journal Institute Science \& Technology, 6: 25-30.

Kaska N., 1995. Pistachio nut growing in Turkey. Acta Horticulturae, 419: 161-164.

Kaya GH., 2003. Dünya'da ve Türkiye'de organik tarımsal ürün ticareti ve tüketici reaksiyonları. www.bahce.biz.com.tr_[Access: February 11, 2018].

Köksal İ., 2002. Türk Fındık Çeşitleri. Fındık Tanıtım Grubu Yayınları, Ankara. 
KPC 2017. Kırmızı antep fıstığı çeşid http://www.fidandeposu.com/kirmizi-cesidi-antepfistigi-fidani [Access: December 15, 2017].

IOF 2018. Introduction to Organic Farming (IOF). http://www.omafra.gov.on.ca/english/crops/facts/09077.htm [Access: February 15, 2018].

MPOPP 2017. Map of provinces having organic pistachio production. https: //www. google. com.tr/maps/@39.3243502,35.0595584,6.25z?hl=tr [Acc ess: June 1, 2017].

OTKS 2018. OTKS, 2018. Organik tarımda kontrol ve sertifikasyon http://bahce bitkileri.cu.edu.tr/upload/ nturemis/sertifikasyon.pdf [Access: February 1, 2018].

OTN 2017. Organik tarım nedir [OTN]. http://www.ekotar.com/TR/Icerik/Index/5/11/35/organik_tarim_nedir [Access: February 1, 2018].

PT 2017. Antep fıstığı ağacı https://www.fistik.gen.tr/antepfistigi-agaci.html [Access: December 15, 2017].

RG 2017. Resmi Gazete [RG]. Organik, iyi tarım, tohumculuk ve fidan destekleri. https://www.dunya.com/koseyazisi/2017-organik-iyi-tarim-tohumculuk-ve-fidandestekleri/366181 [Access: February 11, 2018].

Rodriguez-Bencomo JJ., Kelebek H., Sonmezdag AS., Rodriguez-Alcala LM., Fontecha J and Selli T., 2015. Characterization of the aroma-active, phenolic, and lipid profiles of the pistachio (Pistacia vera L.) nut as affected by the single and double roasting process. Journal of Agricultural and Food Chemistry, 63(35): 7830-7839.
RTMFAL 2015. Republic of Turkey Ministry of Food, Agriculture and Livestock.. http:// www.tarim.gov.tr [Access: June 1, 2017].

Satil F., Azcan N and Baser KHC., 2003. Fatty acid composition of pistachio nuts in Turkey. Chemistry of Natural Compounds, 39(4).

Soylu, 1984. Kestane Yetiştiriciliği ve Özellikleri. Atatürk Bahçe Kültürleri Araştırma Enstitüsü, Yayın No: 59, Yalova.

SP 2017. Siirt fıstığı http://www.fidandeposu.com/siirtcesidi-antep-fistigi-fidani [Access: December 15, 2017].

SPC 2017. Bazı antep fıstığı çeşitleri http://www.tadim.com.tr/bilgidetay/Antep-Fistigi/59 [Access: December 15, 2017].

Sykes JT, 1975. The Influence of climate on the regional distribution of nut crops in Turkey. Economic Botany, 29(2): 108-115.

Şimşek M., 2013. Gübreler ve Gübreleme Ders notları: [in Turkish].

Şimşek M., 2015. A research on almond growing in Turkey and the state of selection studies. Dicle University Journal of Institute of Natural and Applied Science, 4: 95-100.

Tsantili E., Takidelli C., Christopoulos MV., Lambrinea E., Louskas DR and Roussos A., 2010. Physical, compositional and sensory differences in nuts among pistachio (Pistachia vera L.) varieties. Scientia Horticulturae, 26: 562-568.

TSI 2015. Turkish Statistical Institute (TSI). http://www.turkstat.gov.tr/ Start.do [Access: June 1, 2017]. 